\title{
Exploring Teacher Learning Experiences in one Open University in South Africa: a Training Framework
}

\author{
Anthony Kiryagana Isabirye, Kholeka Constance Moloi \\ Vaal University of Technology, South Africa \\ anthonyi@vut.ac.za,conniem@vut.ac.za
}

\begin{abstract}
This paper explores how academics in one South African Open University, experience learning in order to hasten the impact of their innovative teaching and student learning. It also aims at the formulation of a training framework to guide teacher learning. A qualitative phenomenological research design as advocated by Giorgi and Giorgi (2009) was adopted for this study. The research questions posed were: How do academics experience academic development and which teacher learning framework could be used to enhance academic development for ODL teachers to teach innovatively? The study found that the university introduced an academic training programme to the participants (orientation).The orientation prepared them for practical training (learning). Through learning, they were empowered with skills and competencies (skills acquisition) that enabled them to work (performance) as online teachers. The participants further noted that for a training programme to be successful, it must be long in duration, evaluated and have the support of University management. All the participants learning experiences and concerns were synthesised into a training framework. It was recommended that academic development programmes run for longer durations and should be supported by institutional leadership. An evaluation mechanism should be introduced and adhered to, to ensure achievement of all objectives in every training phase.
\end{abstract}

Keywords: Academic development, Open University, training frame work, Innovative teaching

\section{Introduction}

In this paper we explore how academics in one South African Open University, experienced learning in order to enhance the impact of their innovative teaching, research and scholarship, and more importantly, student learning. For Taylor (2008), teacher learning is about knowledge embedded in practice. Abbot (2014) sees teacher learning as a tool to enhance not only teachers' subject knowledge but education in general. In essence teacher learning is about academic development. Hoadley (2010). Indeed Marshall and Pennington (2009) note the need for individuals and institutions to recognise and acknowledge those teachers who excel with regard to academic development. Given that universities, like in any other industry, are required to measure the performance of employees, in particular academics, in order to improve the quality of services provided (Kaydos, 2000), performance measurements are the norm of the day. For Kaydos, the benefits of performance measurements are to motivate the organisation and to help change its culture. This is significant within universities where intellectual capital has now come of age as a field both of research and practice (Viedma Marta \& do Rosário Cabrita, 2012). In line with this thought, Marshall and Pennington (2009) suggest that academic development for teachers should be a must especially in light of the changing roles of academics, increasing university needs and diverse student needs. Based on the importance and necessity of academic development, Marshall and Pennington (2009) observe that some institutions have undertaken major changes; linking promotion and selection procedures to academic development. While academics whose major focus is on research and publication may question the essence of paying more attention to teaching (Marshall and Pennington, 2009), Fry and Kentteridge (2009) point out the necessity of teaching research as a way of preparing University teachers to teach research. The purpose of this paper is to share the experiences of how teachers learn in one Open University in South Africa. We also provide a framework for training teachers in higher education within the South African context.

Problem statement: Research by Taylor (2008) indicates that the reason why the South African system fails to deliver quality results, often points to the failure of basic education (that is primary and secondary school education) to prepare student for tertiary education. Van der Berg and Louw (2008) and Hoadley (2010) argue that very few matriculates obtain university qualifications. Some examples they cited are that nearly one out of three of those students who obtain matric never go for tertiary education. Among those who are able to get passes that enable them to enter tertiary education, university access is often skewed against black students. Thus, black students appear to be at a disadvantage in terms of completing undergraduate 
programmes relative to students from other race groups. Boughey (2010) cautions that despite data she collected from a study that was conducted in two universities of technology in South Africa, the overwhelming construction of students in the data is as 'disadvantaged' where the term 'disadvantaged' is linked to students' previous educational experience. She argues that this sort of understanding of what it means to be 'disadvantaged' can be rendered problematic with the use of theory and research which questions the extent to which schools can do to prepare students for higher education. Large differences in access to undergraduate degree programme remain evident in South Africa. Many matriculates who go to university only do so two or more years after finishing school; the majority drop out without completing the qualifications for which they enrolled. Given that methods of teaching and learning are changing due to the use of computer, information and communication technology (ICT), how do university academics bridge the knowledge gap that new entrants into tertiary education bring along?

Research questions: The main research questions that guide this study is:

- Which teacher learning framework can be used to enhance academic development for innovative teaching?

- How do academics experience learning for innovative teaching?

Aims of the study: The main aim of this study is to:

- Suggest a training framework that can be used to enhance academic development for innovative teaching.

- Explore and describe teacher learning experiences.

\section{Literature Review}

Fry and Ketteridge (2009:468) indicate that globally early career academics are usually asked to build their research, publication, management, teaching and supervision expertise while also undertaking a formal programme of academic development. They suggest that the latter (academic development), relates largely to the teaching and supervision role. Boughey (2010) suggests that in developed countries, the development of capacity and of research on teaching and learning has been an issue which has been addressed through the establishment of a national coordinating structure. A case in point, the author suggests, is the Higher Education Academic in Britain, where a range of policy and other developments are available to structure improvements in teaching and learning. According to Bourghey, arguably what is needed is a national structure which will contribute to the development of capacity at institutional level to work with policy and other developments to maximise their effects.

Marshall and Pennington (2009) suggest that progressive human resource policies have seen the widespread adoption of job evaluation schemes aimed at parity of esteem and reward between different career routes and greater transparency in grading decisions. They point out that as HR policies and procedures have become more codified, HEIs have also recognised the imperative of retaining flexibility and responsiveness to both individual cases and their own circumstances. Where once the nature, volume and scope of individual professional development for teaching was a private matter it is now clearly in the public domain and subject to various forms of review and regulation. Appraisal of performance, quality assurance procedures, institutional and subject-level audits and requirements for professional body membership have exposed a once 'secret garden (Marshall \& Pennington, 2009).

Quinn (2012) argues that re-imagining a purpose for academic development ought to provide a strong moral compass for the work. Boughey (2010) argues that academics are required to retrain and upgrade their teaching skills and competencies, particularly as suggested by Development Bank of South Africa (2012), with the expansion of information and communication technologies that require changed methods of teaching and learning. In this regard, Boughey (2007), suggest that academic development (AD) is an 'open' set of practices concerned with improving the quality of teaching and learning in higher education. She further suggests that 'open' is an attempt to capture that, AD also constitutes student practices. For this reason, they are of the view that AD work often stems from very different ideological and discursive positions. Abbot (2014) suggests that terms and phases such as sustained, intensive, on-going, comprehensive, aligned, collaborative, continuous, 
systematic or capacity-building, as well as relevant to teacher work and connected to student learning, are often used in reference to academic development that is considered to be of higher quality.

Whilst teaching traditionally entails mere information transmission to inactive students, innovative teaching actively involves the students (Neo \& Neo, 2001). This means that academics have to develop new approaches to teacher learning on their campuses, approaches that create real changes in teacher practice and improve student achievement. Hence, the real challenge universities face is how to create opportunities for teachers to grow and develop in their practice so that they, in turn, can help students grow and develop their knowledge and ability to think critically. Universities must consider how teachers learn and adopt new techniques for instruction and tailor the training accordingly. Meeting the new demands of standards-based reform will mean universities must not only change their approach to student learning, but teacher learning. In this regard, teacher learning and student development are intractably linked, and can thus not be viewed separate from each other. Thus, higher education institutions strive to retrain academics to equip them with vital skills, particularly due to the nature of the knowledge economy of today that increasingly demands academics with high level of technical and social skill, knowledge and expertise to meet the demands of a constantly changing, competitive environment (Botha \& Coetzee, 2012). In this regard, Boughey's (2010) early initiatives on academic development (AD) in universities are in line with the aspirations of the South African National Development Plan (2030) that seek to ensure access to higher education, equity and quality for all without discrimination. In this regard teacher learning is epitomised by continuous improvement for organisational excellence and student learning.

Research Design: In order to collect the required data for this study, we used a qualitative interpretive design of a phenomenological genre. It was envisaged that such a design would enable the collection of the respondents' subjective experiences concerning teacher learning and academic development (Giorgi \& Giorgi, 2003; 2009). We believed that phenomenology would also enable access to detailed respondents' academic development experiences that we required.

Sampling strategies: Participants were purposefully chosen to provide information needed in this study (Gall, Gall \& Borg, 2007). Required data was also obtained through reputational sampling. In this regard we selected the respondents based on the recommendation of key informants. Such informants had information about the participants which we were not privy to. Such sampling was appropriate since chosen participants were required to meet specific criteria (Trochim \& Donnelly, 2008). They should have been continuously been employed by the institution for a couple of years; and taken part in the institution's academic development activities.

\section{Methodology}

Semi-structured phenomenological interviews were used. The interviews involve a number of phases namely: familiarization with the respondents, the interview audio-recording and transcribing the interviews (Giorgi, 2009). In line with Giorgi's (2009) and Englander's (2012) recommendation, we focused on obtaining the participants' complete description of their experiences. To further meet the phenomelogical criteria of phenomenological interviews, probes that were geared towards participants' staff development experiences (Giorgi, 2009) were made use of. Interview documentation was done through audio-recordings. We also made notes during the interview process for further analysis. The field notes were used as a measure of triangulation, in addition to capturing respondents' mannerisms during interview sessions. Interviewees' collation between the participants' responses and mannerisms enabled us to identify any contradiction between their vocalization and non-verbal signals. The notes were also used to document the products of coding; examine the codes further; establish and ascertain the relationship between the different categories, as well as exploring gaps in the formed categories (Dooley, 2002; Charmaz, 2003).

Data analysis: Data were analysed following the dictates of phenomenology as advocated by Giorgi and Giorgi's (2003). This entailed recording and transcribing the interviews. We then individually listened to each transcribed interview several times. This enabled us to get a general picture of what the participants were saying. We identified words and phrase (units of meaning) that carried similar meanings in each of the transcripts. The identified words and phrases were regrouped according to what they indicated about the 
respondents' experiences and given a general name which epitomised what each unit in the cluster said (Giorgi, 2009; Giorgi \& Giorgi, 2003; Giorgi, 1986). The transcribed interviews were then analyzed according to Giorgi's phenomenological approach (Giorgi, 1986; 1989; 2009). Each general description indicated a different experience as lived by the academics (Giorgi \& Giorgi, 2003, 2009).

Credibility: To ensure the credibility of the study, we rendered consistent explanations giving reasons for the research design and methodology (Morse, Barrett, Mayan, Olson \& Spiers, 2002). A comprehensible and justifiable connection linking all phases of the study from data collection to reporting the results was presented. Furthermore, as advocated by Creswell and Miller (2000), we deciphered and gave data logically against the backdrop of the empirical findings. To avoid tenting the results, our own predetermined beliefs and ideas that were likely to impact on the results were acknowledged beforehand and avoided (Maritz \& Visagie, 2010).

Ethical considerations: Permission to conduct this study was got from the ethical committee of the University. All respondents were informed about the study and its purpose and their participation was voluntary. They were also allowed the freedom to withdraw from the study at any one moment if they felt uncomfortable. Anonymity of all participants was assured and we emphasised that and answers given by the respondents would be used for no other purpose other than 'advance scholarly research and improve academic practise (Shammo \& Resnik, 2009).

\section{Results}

Six academics took part in the study. Each academic was given a code name L1, representing the first academic to be interviewed and L6, representing the last one. The respondents' revealed that they were introduced to the training programme (orientation) following which they exposed to learning activities (learning).Through learning they got the required skills and competencies (skills acquisition) to work (performance) as online teachers. They indeed indicated that for them, professional development was a change experience as it changed their teaching approach. Notwithstanding their positive experiences, the respondents had three major concerns which required the attention of the institution. In order to further enhance their training and learning experiences. They decried the short period in which the development programme had to be accomplished. They were also concerned about the little (time) they had to accomplish the authentic exercises during the practical exercises. They further noted the absence of a mechanism to ascertain the accomplishment of the training goals (evaluation). Finally all the participants noted that for such a training programme to be successful, it requires the support of the institution (university support).

Discussion and formulation of the training framework: The results as given above were synthesised into a training framework following Boulter and Buckley's (2000), Halloun's (2007) and Morse's (2004) recommendations of model building. By analysing the respondents 'lived experiences, we formulated a comprehensive, logical, parsimonious, and consistent framework (Morse, 2004). The formulated framework mirrors the findings of the study. 


\section{The training framework for teacher learning and academic development}

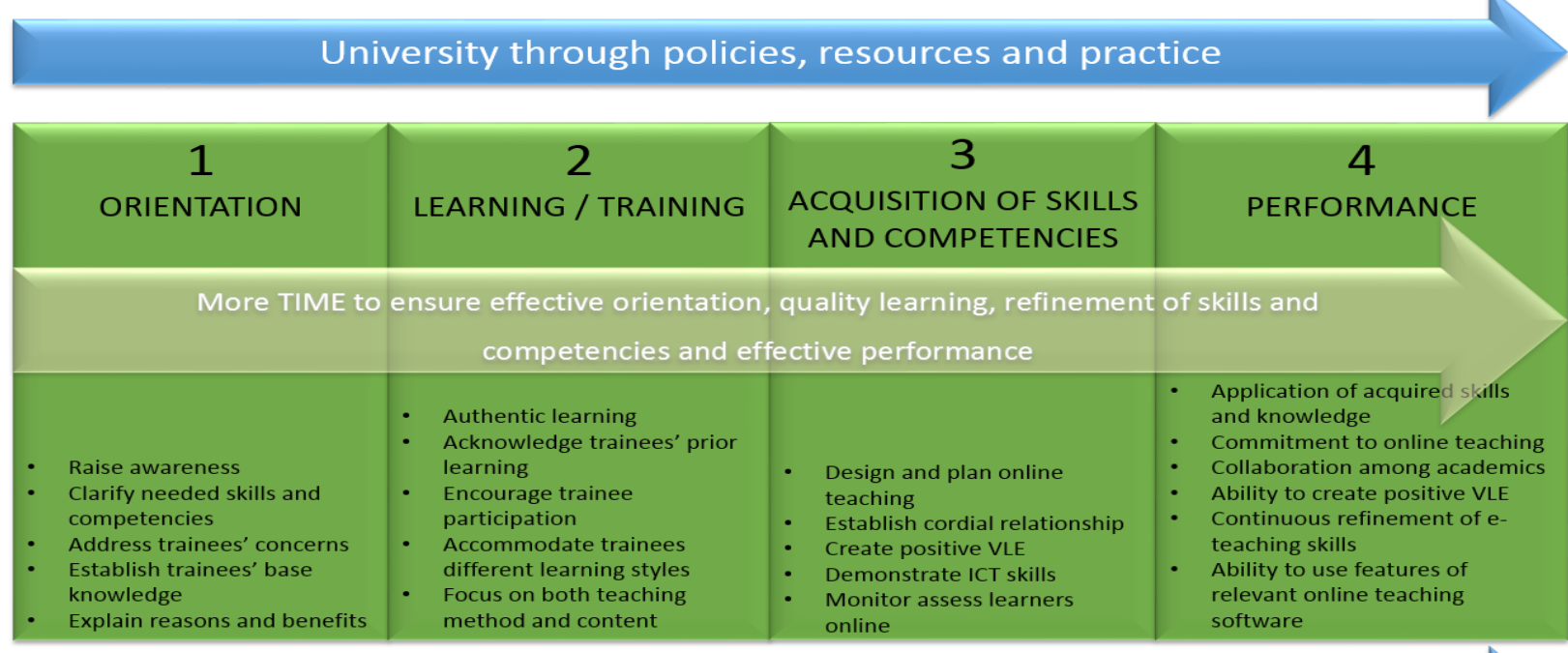

Evaluation (ascertain achievement of objectives at each level)

Orientation: The participants in this study revealed that they attended an orientation session at the outset of the training. Through this session, programme facilitators did not only raise awareness of the programme but also clarified the skills and competencies that the academics were supposed to have in order to teach online. Furthermore all respondents indicated that through the orientation sessions trainers established their base knowledge and skills and explained the benefits that they, as on learn teachers were expected to get from the planned training. Some of the trainees concerns were also addressed during this time. All participants agreed that the orientation experience was quite a rewarding one. L2 for example indicated the orientation experience prepared him and the colleagues for the future training sessions. Similarly L3 indicated that "before the actual training we attended a session in which we were briefed on what is it that we were going to do" (in the next sessions). Phrases to that effect also resonated in L4, L5 and L6's description. Describing the experience for instance, L4 indicated that, “...the first meetings were all about introducing us to online teaching, what it was, why the university was adopting it as the major delivery method..."

Since all respondents experienced a positive orientation session, "orientation" was identified as a phase that is vital in a training programme. This observation is in line with a number of other studies in education that emphasise the importance of trainee orientation. In this regard Dickhauser, Butler and Tonjes (2007) posit that orientation programmes do not only motivate trainees, but they also reveal what is required of the participants during the course of executing their roles (Kagan, 1992). This is important given the fact that adult learners prefer to learn only that, that is relevant to their goals (Collins, 2009; Cercone, 2008). In light of the finding that orientation could serve as a positive experience for trainees, it is vital that training facilitators establish the reasons for the trainees' participation in a training programme through an orientation exercise. According to Erasmus et al. (2012) adult participation in a training programme could also be motivated by the need of achievement, self-esteem, self-confidence, competence and self-actualisation. It is therefore vital that during the orientation phase, most prominent reasons (Kagan, 1992; Mc Loughlin \& Oliver, 2000; Collin, 2009) for the learners' participation in the course are identified and addressed.

Learning/training: Participants revealed their experiences as they partook in the different learning sessions. In such sessions they were given real and practical activities connected with online teaching. In the words of L4, "It was a practical training... we dealt with the making of learning schedules and uploading them on line..."

In a similar vein, L5, indicated "in these sessions we became students, engaging ourselves in practical work that was designed to enhance our e-teaching skills." With regard to L6, "the sessions after orientation were enjoyable but challenging...we went practical. All lecturers teaching a particular module worked together to identify the essential elements of the modules we taught." 
Apart from being exposed to authentic and practical learning activities, participants revealed that during this phase facilitators solicited their prior knowledge with regard to online teaching, and encouraged them to fully participate in all the activities. This finding is consistent with the literature in adult learning. According to Gravett (2001) and Cercone (2008) adult learn better when exposed to authentic and practical activities that are related to their world of work. As adults, academics would also prefer a training program that is selfdirecting, interactive and collaborative (Collin, 2009; Knowles, Holton, \& Swanson, 2005). Not surprisingly, participants in this study indicated that they liked the partial autonomy they enjoyed as trainees, the participation, collaboration and the interaction that characterized the training programme during this phase. Describing his experience during the learning phase, L6 stated thus:

"I liked the way we worked together as a group. I experienced working with those who were better than me in the use of computers and we solved all the challenges jointly. And I think the idea of the trainer letting us solve the challenges on our own was also good because it made us learn better."

From L6's response which serves as an epitome of all the other responses it can be stated that apart from experiencing participative, collaborative and interactive learning, participants also experienced some form of self-directed learning. This finding is supported by the available literature on adult education. Knowles, Holton and Swanson (2005) and Marthur et al. (2009) for instance emphasises the need to accord adult learners some form of autonomy during the training programmes; while Cercone (2008) and Gravett, (2001) add the need to treat adult learners with respect. It is this independence, interaction, collaboration among the learners and the accorded respect that enhances their learning (Mc Loughlin \& Oliver, 2000).

Skills and knowledge acquisition: Participants indicated due to the activities as undertaken in the learning phase, they acquired the competencies and skills to design and plan online teaching, to establish cordial relationships with their students online, create positive virtual learning environments, and demonstrate ICT skills and to monitor assess learners on line. The sentiments of five of the respondents are captured in the following excerpts.

L2: I'm able to teach online today because of this training....

L3: We were also trained how to engage students online...creating interesting activities and how to encourage them to come on line..."

L4: It was an experience as we were trained how to write scripts for audio podcasts. We also focused on editing, recording and uploading learning resources on the net.

L5: It was quite a busy week of intensive training as we touched almost all the online text tools that we use on my Unisa. We familiarised ourselves with such tools as the welcome or homepage, announcements, discussion forums...of my Unisa."

L6: We worked as teams, discussed the necessary components of our modules.... we were asked to put them online practically."

It is evident that 'orientation' and 'learning' empowered the respondents, by way of enabling them to acquire and use the required skills and competencies. Through this phase trainees were transformed into qualified online teachers (Spector \& La Teja, 2001) through the acquisition of online teaching skills. The literature on training online teachers emphasise that if individuals have to successfully work in virtual learning environments, they have to muster several competencies required of ODL teachers. According to Egan and Akdere (2005) such competencies can be generally identified as communicative, managerial and administrative, technological and instructive competencies.

Performance: Through executing and exposure to the activities in the orientation, training and skills acquisition phases, participants became potent and competent online communicators (Egan \& Akdere, 2005); transforming into effective and efficient online teachers. Indeed asked how the training programme had impacted on them the participants responded thus"

L1 I can now apply what we learnt practically.

L2 I'm now more committed to online teaching than before.

L3: The programme has empowered me because am able create a positive VLE environment

Notwithstanding the positive training experiences as revealed during the different phases of training, all the respondents expressed a number of concerns, which if addressed could enhance the positive learning 
experiences. They felt the need for increased university support of the training programmes, the need for more time to ensure effective orientation and quality learning. Refinement of skills and competencies and attaining effective performance also required more time. All these concerns are reflected in the formulated training framework. Talking about the need for university support, the participants indicated that a teachers' professional development programme need be supported by all stakeholders. This is in line with Hunter and Austin's (2004), Collin's (2009), Leu and Ginsburg's (2011) assertion that a supportive context in which training should thrive entails the entire university, its senior and junior managers, the lecturers and the students.

With regard to time, the literature indicates that it is essential for crystallization of acquired skills by the trainees. Indeed effective professional development requires long durations (Garet, Porter, Supovitz \& Turner, 2000). Indeed in this study participants revealed the need for longer duration of time during all phases of the training. In their own words they stated thus:

L1: I needed more time to grasp everything well

L5: The programme was hurriedly completed.

L6: we needed a lot of time to complete the class activities.

L2: The program was ok but we needed more time to learn better

The above views were in line with the findings of other studies (Supovitz \& Turner, 2000). In their study structured to find out how staff development could lead to quality teacher instruction in the United States, it was discovered that the longer the duration of the training programme, the better the quality of teacher instruction. On the other hand, Van Menon's (1990) study concluded that successful development requires a lot of time since change does not take place overnight. Supporting the findings of Supovitz and Turner (2000) and Van Menon (1990), Dori and Herscovitz's (2005) three year study came to a conclusion that a lot of time was required to change teachers' instructional methods. The third and last concern as expressed by the respondents was the absence of an evaluation mechanism which would ensure that all the objects as set out in each of the training phases were aptly achieved.

Recommendations: A description of teachers' academic development experiences has been given in this study. From the experiences a framework that could be used to guide academic development was constructed. The framework does not only indicate what the responded perceived as major components of a training programme, but it also identifies their concerns which, if attended to, could enhance positive learning experiences. Based on the findings, there is need to attend to the questions of managerial and administrative support, duration of training programmes and the question of putting a proper evaluation mechanism to ensure effective development programmes.

\section{Conclusion}

This study explored learning experiences and concerns for academics at a South African ODL University. To access the experiences as lived by the respondents, phenomenological qualitative research design was adapted. Following the sciences of model building and the recommendations of Morse (2004), the experiences were synthesized into a staff development frame work. From the formulated frame work, it became evident that effective staff development commences with trainees orientation. Orientation prepares trainees for learning, acquisition of skills and eventual performance as teachers .But for effective training to occur, respondents observed that the programme should be supported by the institution, allowed enough time and be evaluated to ensure that expected outcomes in each phase are achieved.

\section{References}

Abbot, S. E. (2014). Personalized learning. Glossary of educational reform. Available: http://edglossary.org/personalized-learning/. Accessed: 11/28/2016.

Botha, J. \& Cotzee, N. (2012). The Psychology of learning, Employee motivation and performance. In Cotzee, M. (Ed.), Practicing Training and Development in South African Organisations. $2^{\text {nd }}$ Ed. Lansdowne, Cape Town: Juta 
Boughey, C. (2007). Educational Development in South Africa: From social reproduction to capitalist expansion. Education Policy, 20, 5-10

Boughey, C. (2010). Academic development for improved efficiency in the higher education and training system in South Africa. Development Bank of South Africa.

Boulter, C. J. \& Buckley, B. C. (2000). Constructing a typology of models for science education. In Gilbert, J.K. \& Boulter, C.J. (Eds.), Developing models in science education, (pp.41-57). Dortrecht: Kluwer: Academic Publishers.

Cercone, K. (2008). Characteristics of adult learners with implications for online learning design. AACE Journal, 16(2), 137 - 159.

Charmaz, K. (2003). Qualitative interviewing and grounded theory analysis. In J.F. Gubrium and J.A. Holstein (Eds.), Handbook of Interview Research: Context and Method. (pp. 675 - 694). London: Sage.

Collin, K. (2009). Work-related identity in individual and social learning at work. Journal of Workplace Learning, 21(1), 23-35.

Creswell, J. W. \& Miller, D. L. (2000). Determining validity in qualitative inquiry. Theory into practice, 39(3), 124-130.

Development Bank of South Africa. (2012). Project preparation challenges: Improving project financing for local government infrastructure development. Round table held on the $26^{\text {th }}$ January, 2012.Midrand: Development Bank of South Africa.

Dickhauser, O., Butler, R. \& Tones, B. (2007). Das Zeigt doch nur, dass inch's nicht kann-Zielorientierung und gegenuber Hilf bei Lehramtisan wartern [That just shows that I can't do it: Goal orientation and attitudes concerning help among pre-service teachers]. Zeitschrift fur Entwicklung spsycholgie und padagogische psychlogie, $39120-126$.

Dooley, L. M. (2002). Case study research and theory building. Advances in Developing Human Resources, 4(3), 34-353.

Dori, Y. J. \& Herscovitz, O. (2005). Case-based long-term professional development of science teachers. International Journal of Science Education, 27(12), 1413-1446.

Egan, T. M., \& Akdere, M. (2005). Clarifying distance education roles and competencies: Exploring similarities and differences between professional and student-practitioner perspectives. The American Journal of Distance Education, 19(2), 87-103.

Englander, M. (2012). The interview: Data collection in descriptive phenomenological human science research. Journal of Phenomenological Psychology, 43(2012), 13 -35.

Erasmus, B. J., Loedolff, P. V. Z., Mda. T. V. \& Nel, P. S. (2012). Managing Training and Development. Cape Town: Oxford.

Fry, H. \& Ketteridge, S. (2009). Enhancing personal practice. Establishing teaching and learning credentials. In: H. Fry; S. Ketteridge \& S. Marshall (Eds.). A Handbook for teaching and learning in higher education. Enhancing academic excellence. Third Ed. London: Routledge, Taylor \& Francis Group, pp. 468-484.

Gall, M. D., Gall, J. P. \& Borg, W. R. (2007). Educational research: An introduction (8th Ed.). Boston: Pearson.

Giorgi, A. (1986). A phenomenological analysis of descriptions of concepts of learning obtained from a phenomenological perspective. Available at: http://books.google.co.za/books/about/A_Phenomenological_Analysis_of_Descripti.html?id=GYXEtg AACAAJ\&redir_esc=y (accessed on 10/7/2014).

Giorgi, A. (1989). One type of analysis of descriptive data: Procedures involved in following a scientific phenomenological methods. Methods, 4(3), 39-61.

Giorgi, A. (2009). The descriptive phenomenological method in psychology: A modified Husserlian approach. Pittsburgh, PA: Duquesne University Press.

Giorgi, A. P. \& Giorgi, B. M. (2003). The descriptive phenomenological psychological method. In P. Comic, J.E. Rhodes \& L. Yardley (Eds.). Qualitative Research in Psychology (pp.243-273). Washington DC: American Psychological Association.

Gravett, S. (2001). Adult learning: Designing and implementing learning events - a dialogic approach. Pretoria: Van Schaik.

Halloun, I. A. (2007). Mediated modelling in science education. Science \& Education, 16(7-8), 653-697.

Hoadley, U. (2010). What do we know about teaching and learning in primary schools in South Africa? A review of the classroom-based research literature. A report for the Grade 3 Improvement project of 
the University of Stellenbosch, supported by the Western Cape Education Department and the Western Cape Provincial Treasury. University of Cape Town.

Hunter, C. \& Austin, L. (2004). Supporting lecturers in their move towards a new a learning environment. Available at: http://www.col.org/pcf3/papers/PDFs/Hunter_Austin.pdf (Accessed on 13/7/2012).

Kagan, D. M. (1992). Implication of research on teacher belief. Educational psychologist, 27(1), 65-90.

Kaydos, W. (2000). Operational performance measurement. Increasing total productivity. Boca Raton, Florida: CRC Press.

Knowles, M. S., Holton III, E. F. \& Swanson, R. A. (2005). The adult leaner. The Definitive Classic in Adult education and Human Resource Development (6 ${ }^{\text {th }}$ Ed.), Burlington, MA: Elsevier.

Leu, E. \& Ginsburg, M. (2011). First Principles: Designing effective Education Program for In-service Lecturer Professional Development. Washington, DC: USAID.

Maritz, J. \& Visagie, R. (2010). Methodological Rigour and Ethics of Accountability within a Qualitative framework. Paper presented to academic staff at Unisa. Pretoria.

Marshall, S. \& Pennington, G. (2009). Teaching excellence as a vehicle for career progression. In: H. Fry; S. Ketteridge \& S. Marshall (Eds.). A Handbook for teaching and learning in higher education. Enhancing academic excellence. Third Ed. London: Routledge, Taylor \& Francis Group, pp.487-512.

Mathur, S. R., Clark, H. G. \& Schoenfeld, N. A. (2009). Professional Development: A capacity - Building Model for Juvenile Correctional Education Systems. The Journal of Correctional Education, 60(2), 164 - 186.

McLoughlin, C. \& Oliver, R. (2000). Designing learning environments for cultural inclusivity: A case study of indigenous online learning at tertiary level. Australian Journal of Educational Technology, 16(1), 5872.

Morse, J. M. (2004). Constructing qualitatively derived theory: concept construction and concept typologies. Qualitative Health Research, 14(10), 1387-1395.

Morse, J. M., Barrett, M. \& Mayan, M. (2002). Verification strategies for establishing reliability and validity in qualitative research-ejournals. library-ualberta.ca Available at: http://www.ualberta.ca/ iiqm/backissues/1_2Final/pdf/morseetal.pdf (Accessed on 7/10/2011).

Neo, M. \& Neo, K. T. K. (2001). Innovative teaching: Using multimedia in a problem-based learning environment. Educational Technology \& Society, 4(4), 1- 18.

Shamoo, A. \& Resnik, D. (2009). Responsible Conduct of Research, 2nd ed. New York: Oxford University Press

Spector, J. M. \& La Teja. (2001). Competencies for Online Teaching. Eric Digest. Dec. Available at: http (Accessed on 12/10/2012).

Quinn, L. (2012). Re-imagining academic staff development: Spaces for disruption. AFRICAN SUN MeDIA.

Supovitz, J. \& Turner, H. M. (2000). The effects of professional development on science teaching practices and classroom culture. Journal of Research in Science Teaching, 37, 963-980

Taylor, N. (2008). Whats wrong with South African schools? Available: JET Education Services: www.jet.org.za. (Accessed: 11/28/2016.)

Trochim, W. M. \& Donnelly, J. P. (2008). Qualitative and unobtrusive measures. The research methods knowledge base, 2, 151-167.

Van der Berg, S. \& Louw, M. (2008). Lessons learnt from SACMEQII: South African student performance in regional context. In G. C. Bloch, L. Chisholm, B. Fleisch \& M. Van Manen, M. (1990). Researching lived experience: Human Science for an Action Sensitive Pedagogy. Albany, N.Y: State University of New York Press.

Viedma Marti, J. M. \& do RosárioCabrita, M. (2012). Entrepreneurial excellence in the knowledge economy. Intellectual capital benchmarking systems. London: Palgrave Macmillan. 